DAKWATOLOGI KOMUNIKASI DAN TITIK BIAS KOMUNIKASI

\title{
Aep Wahyudin
}

(Dosen Fakultas Dakwah dan Komunikasi UIN SGD Bandung)

\section{Abstract:}

Building a paradigm of Islamic communication does not have to start from scratch. In terms of synthesis base, it can use conventional communication theories. However, it is the task of Muslim intellectuals and scholars to make a new synthesis through metatheoritical aspects, which includes epistemology, ontology and perspective. Aspects of values and ethics should be able to collaborate with monotheism and divine responsibility. The function of communication in Islam is to realize the same meaning, leading to changes in the attitudes or behavior of the Muslim community. In the meantime, the ultimate goal of communication in Islam is the happiness in this world and the hereafter, which emphasizes on communication aspects, not communicator. In social change and community development, conventional communication tends to be positivistic and functional and is oriented to individual, not a whole social system. The values of communication such as truth, simplicity, kindness, honesty, integrity, fairness, the validity of message and source, become an important aspect of communication in Islam. On this perspective, Islam is established on the triangular relationship between God, man and society.

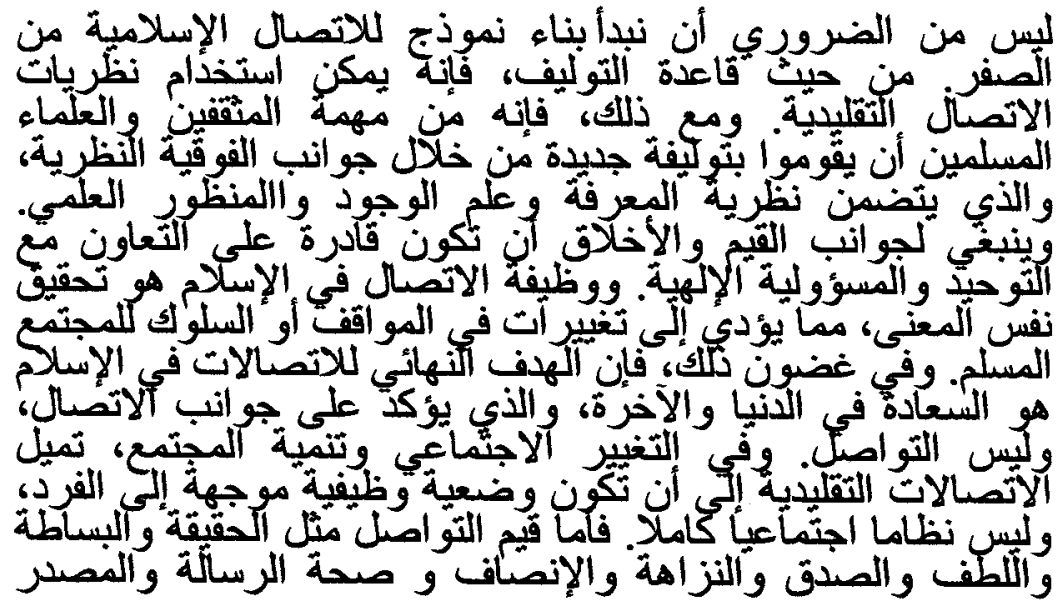




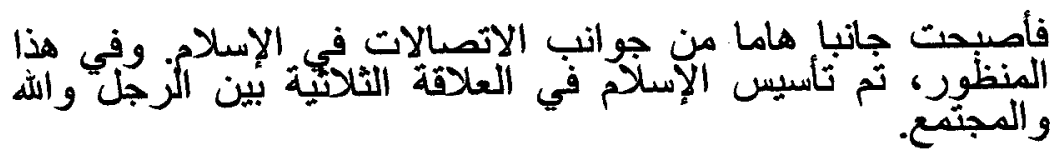

Kata Kunci : dakwah, komunikasi islam, epistemologi.

\section{Pendahuluan}

Littlejohn SW (1978), dalam "Theories of Human Communication", mengungkapkan kajian komunikasi merupakan studi interdisipliner yang menyelidiki proses komunikasi dengan menggunakan pandangan dari berbagai disiplin ilmu traditional (sosiologi, psikologi, antropologi, dan filsafat). ${ }^{1}$ Secara kajian studi Islam (Islamic studies), dengan pendekatan antar disipliner, komunikasi juga dapat dipahami dalam ilmu dan pengetahuan ke-Islam-an. Pendekatan terhadap hal ini telah dilakukan, misalnya oleh Imtiaz Hasnain dengan "Communication: An Islamic Approach", dan Muhammad Yusof Hussein "Islamization of Communication Theory". 2

Rumusan definisi komunikasi banyak sekali, sebagai gambaran "entry point' memahami komunikasi, menurut Berker,"process that involves interdependent an interpreted element working togather to achieve desired goal or out come". ${ }^{3}$ Berelson dan Steiner menyatakan komunikasi sebagai proses penyampaian informasi, emosi, ketrampilan, dengan menggunakan simbol, kata, gambar, angka, dan sebagainya. Dan, menurut Carl I.

\footnotetext{
${ }^{1}$ Ahmad Kamil Muhammed, Communication As an Academic Discipline, terj. (Komunikasi sebagai suatu disiplin Akademis), dalam Jurnal Komunikasi Audientia, (Vol 1. No. 1 Januari-Maret 1993; Bandung: Rosdakarya), h. 1. Disarikan dari Littlejohn SW, "Theories of Human Communication", (Colombus, Ohio: Charles E Merril).

Imtiaz Hasnain, Communication: An Islamic Approach, terj. (Komunikasi Menurut Pendekatan Islam). Dalam Jurnal Komunikasi Audienta, Ibid., h. 15

${ }^{3}$ Lary Barker, Communication, (New Jersey: Prentic Hall Inc. 1984), p. 425 
Hovland, adalah upaya yang sistematis untuk merumuskan secara tegar asas-asas penyampaian informasi serta pembentukan pendapat dan sikap, bahkan secara khusus "communication is the process to modify the behavior of other individuals" (komunikas adalah proses mengubah prilaku orang lain) ${ }^{4}$

Berdasar dari pengertian di atas, secara bahasan akademis dapat diidentifikasi bahwa ilmu komunikasi secara umum dapat disebut (memiliki kesamaan) dengan dakwah. Keduanya memiliki proses transformasi, internalisasi dan eksternalisasi pesan (message). Karena kegiatan dakwah Islam merupakan syi'ar dan penerangan Islam atau komunikasi dan penyiaran Islam yang terdiri dari: transformasi, sosialisasi, internalisasi, dan eksternalisasi ajaran Islam dengan menggunakan metode (sarana) untuk mencapai tujuan. ${ }^{5}$

Dalam Alqurān disebutkan term-term yang berkaitan dengan dakwah : Allah sebagai da'i (yang menyeru, memanggil dan mengajak dalam komunikasi bisa disebut komunikator) sebanyak 980 kali, Nabi (sebagai penyampai informasi Ilahiyah) sebanyak 154 kali dalam 43 bentuk, dakwah sebanyak 208 kali dalam 70 bentuk, tabligh (menyampaikan ajaran Islam) sebanyak 77 kali dalam 32 bentuk, lisan 25 kali dalam 7 bentuk, dan term-term lainnya. ${ }^{6}$ Merujuk pada firman Allah:

\footnotetext{
${ }^{4}$ Onong Uchyana Effendi, Ilmu Komunikasi teori dan Praktek, (Bandung: Rosda Karya, 1994), h. 10

${ }^{5}$ Amarullah Ahmad,"Kurikulum Nasional Fakultas Dakwah IAIN', Tim Penyusun Kurikulum Nasional fakultas Dakwah, (1994), h. 4

'Syukriadi Sambas, Ușul al-lthna al-'Ash'ariyah, (Pedoman Matan Wilayah Dakwah Islam), (Fakultas Dakwah IAIN SGD Bandung: 1998), h. 1-2
} 


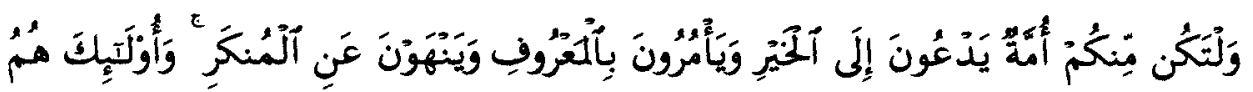

$$
\begin{aligned}
& \text { أَلْمُفلِحُوبَ }
\end{aligned}
$$

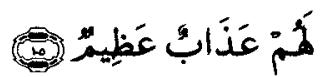

("Dan hendaklah ada diantara kamu sekalian segolongan ummat yang menyeru kepada kebaikan, menyuruh kepada yang ma'ruf dan mencegah yang munkār, mereka itulah orang-orang yang beruntung").

Hadith Rasul menyebutkan;

$$
\begin{aligned}
& \text { وعن عبدالله عمر وين العا صل رضي الله عنه ان النبي ملى الله عليه وسلم قال } \\
& \text { بلغوا عنى ولواية (رواه البخاية ودن العادي) }
\end{aligned}
$$

("Abdullah Bin 'Amr Bin al-Aṣ berkata: Bersabda Rasulullah saw: "sampaikan dari ajaranku walaupun hanya satu ayat.."). ${ }^{8}$

Oleh karena itu komunikasi sebagai suatu bentuk disiplin ilmu sosial yang berkenaan dengan manusia, tidak bisa dipisahkan dengan dakwah yang berkenaan pula dengan manusia. Maka dakwah dapat dipahami dalam beberapa definisi, sebagai berikut :

"Syekh Ali Mahfuz dalam "Hidāyatu al-Murshidīn":

- "Mendorong manusia untuk melakukan kebaikan dan mengikuti petunjuk, memerintahkan berbuat ma'rüf dan mencegah dari berbuat munkar, agar memperoleh kebahagian dunia dan akhirat'. ${ }^{9}$

${ }^{7}$ Q.S. ali 'Imrān (3): 104. Juga ayat-ayat lain yang berkenaan dengan dakwah ini : Q.S. al-Baqarah (2): 186; Q.S. ar-Rūm (30): 25; al-Baqarah (2): 2; al-‘An'ām (6): 52; Q.S. Yunus (10): 25; Q.S. ali 'Imrān (3): 110, dan lain-lain.

${ }^{8}$ An-Nawawy, Riyadu al-Salihin, terj. Jild II. Penterjemah Salim Bahreisy. (Bandung : PT. Al-Ma'arif. 1987), h. 316

${ }^{9}$ Syekh Ali Mahfuz, Hidāyatu al-Murshidīn, (Bairut : Dār al-Ma'arif, Tth), h. 17 
- "Aktualisasi Imani (teologis) yang dimanifestasikan dalam suatu sistem kegiatan manusia beriman dalam bidang kemasyarakatan yang dilakukan secara teratur untuk mempengaruhi cara merasa, berpikir, bersikap dan bertindak manusia pada dataran kenyataan individual dan sosio-kultural dalam rangka mengusahakan terwujudnya ajaran Islam dalam semua segi kehidupan dengan menggunakan cara tertentu". ${ }^{10}$

- "Penyampaian informasi (Islam) yang bukan saja bertujuan supaya orang mengerti dan memahami isi suatu informasi, akan tetapi agar orang meyikini dan menundukan diri pada sisi atau pesan informasi tersebut, yang berisi kegiatan dan proses sosialaisasi idea dan konsep-konsep serta internalisasi nilai dan kaidah ajaran Islam , sehingga hal itu masuk dalam kepribadian seseorang". ${ }^{11}$

- "Dakwah disebut pula komunikasi Islam, sbagai suatu cara yang mengajarkan, mempengaruhi manusia melalui alam pikirannya, dengan tujuan menggubah situasi yang negatif kepada situasi yang positif, memindahkan dari alam kekafiran kepada alam keimanan kepada Allah swt. ${ }^{12}$

- "Seruan atau ajaran kepada keinsafan atau usaha untuk mengubah situasi kepada situasi yang lebih baik dan sempurna, baik kepada pribadi maupun masyarakat". ${ }^{13}$

- "Merupakan tugas suci bagi setiap muslim ketika berada di bumi, yaitu menyeru dan menyampaikan agama Islam kepada masyarakat dan kewajiban tersebut untuk selama-lamanya". ${ }^{14}$

- "Mengajak atau menyeru untuk melakukan kebajikan-kebajikan dan mencegah kemunkaran, merubah ummat dari situasi lain yang lebih baik dalam segala bidang, merealisasikan ajaran Islam dalam kehidupan sehari-hari bagi seorang pribadi, keluarga, kelompok 1985), h. 2

${ }^{10}$ Amrullah Ahmad, Dakwah Islam dan Perubahan Sosial, (Yogyakarta: PLP2M,

${ }^{11}$ Abdul Munir Mulkhan, Paradigma Intelektual Muslim, (Yogyakarta: Sipres. 1994), h. 100

${ }^{12}$ R. Agus Toha Kustawa, Komunikasi Islam, (.Jakarta: Arikha Media Cipta, 1986),

h. 12

${ }^{13}$ M. Quraish Shihab, Membumikan Alqurän, (Bandung: Mizan, 1995), h. 194

${ }^{14} \mathrm{Hafi}$, Anshari, Pemahaman dan pengamalan Dakwah, (Surabaya: Al-Ikhlas. 1993), h. 10 
atau massa serta bagi kehidupan masyarakat sebagai keseluruhan tata kehidupan bersama dalam rangka pembangunan bangsa dan ummat manusia". ${ }^{15}$

- "Sebagai komunikasi mengajak dan memanggil ummat manusia kepada agama Islam, memberi informasi mengenainya, amar ma'ruf nahi munkar, agar dapat tercapai kebahagiaan dunia dan akhirat, dan supaya terlaksananya ketentuan Allah". ${ }^{16}$

\section{Pembahasan}

\section{A. Jejak Histori Komunikasi Dalam Islam}

Untuk mengetahui sejarah komunikasi dalam Islam, maka ia akan terkait dengan tarikh atau sejarah dakwah Islamiyah. Dakwah sebagai komunikasi Islam ini memiliki sejarah yang luas sepanjang sejarah peradaban manusia dalam menyebarkan Islam. Dalam hal ini, komunikasi Islam dalam aspek sejarahnya dapat dibagi dua masa:

\section{Masa Sejarah Dakwah (Komunikasi Islam) Dalam Bentuk Praktis}

Sejarah dakwah itu sangat panjang, semenjak dakwah yang dilakukan oleh Nabi Adam as., sampai kepada Nabi Muhammad saw dan hingga sekarang. Masa kehidupan Muhammad dalam proses mengkomunikasikan Islam terdiri dari periode Makkah dan periode Madinah, kemudian Khulafä' ar-Räshidin, periode Mu'awiyah dan Abasyiyah, hingga masa kebahgkitan kembali Islam. Pada periode tersebut banyak masalah yang dapat diteliti dan dihimpun, hingga dapat menghasilkan teori-teori ilmu dakwah (sebagai komunikasi Islam). ${ }^{17}$

${ }^{15}$ A. H. Hasanuddin, Retorika Dakwah dan Publisistik, (Surabaya: Usaha Nasional, 1982), h. 35

${ }^{16}$ Ahmad Subandi, Ilmu Dakwah, (Bandung: Yayasan Syahida, 1994), h. 18

${ }^{17}$ DR. Wardi Bachtiar, Metodologi Penelitian Ilmu Dakwah, (Bandung: Logos. 1997), h. 36 
Kedudukan Rasulullah dalam kaitannya dengan dakwah (dalam mengkomunikasikan pesan-pesan Islam). Maka seluruh perilaku kehidupan rasol merupakan perilaku dakwah, artinya dakwah tak bisa dilepaskan Islam sebagai agama tersebut, mengamalkan Islam berarti mengamalkan dakwah. ${ }^{18}$ Sejarah Dakwah Islamiyah dimulai sejak tanggal 17 ramadlan, dua belas tahu sebelum hijrah (6 Agustus 610) pada waktu Muhammad diangkat menjadi Rasulullah dengan tugas "risalah"-nya yang pertama untuk membudayakan ummat manusia dengan perintah wajib membasmi buta huruf dan mengembangkan ilmu pengetahuan. Tergambar dalam surat yang pertama kali diturunkan:"Bacalah (iqra') dengan nama Tuhanmu...". ${ }^{19}$ Hal ini ditegaskan Allah terjadi pada bulan ramadlan. ${ }^{20}$ Peristiwa ini merupakan titik awal dakwah Islamiyah. ${ }^{21}$ Digambarkan Sayyid Quțub, hal itu sebagai peristiwa besar, besarnya tiada bertepi, tak mampu mengelilinginya, karena mempunyai segi-segi yang banyak sekali. ${ }^{22}$ Pada masa rasul pun, di Arab ada tradisi pertandingan sya'ir yang mengandung nilai sastra yang tinggi yang berlokasi di pasar ukaz, karena orang-orang Arab memiliki kepandaian sastra yang tinggi. Yang secara praktis, itu merupakan teknik komunikasi yang memiliki nilai pesan (isi) sastra.

\footnotetext{
${ }^{18}$ Mulkhan, Paradigma....., h. 101

${ }^{19}$ Q.S. al-'Alaq (96): 1-5

${ }^{20}$ Q.S. al-Baqarah (2): 185

${ }^{21}$ A. Hasymy, Dustur Dakwah Menurut Alqurān, (Jakarta: Bulan Bintang, 1994), h. 45

${ }^{22}$ Syyid Quṭu, Tafsir fi Dilal Alqurān, Jilid viii, Juz xxx, cet ke-3, (Bairut: Ihyã at Turāsi al-'Araby, tth), h. 198
} 
Aep Wahyudin, Dakwatologi Komunikasi dan Titik Bias Komunikasi

Kemudian proses dakwah dalam mengkomunikasikan pesan-pesan Ilahiyah, menurut Hamzah Ya'kub (1981) dapat dilihat dari sisi ukurannya sebagai berikut :

a. Dakwah (Komunikasi Islam) secara Diam-diam

Setelah Nabi menerima 7 ayat pertama surah al-Mudathir, yang maksudnya supaya Nabi bangkit memberikat peringatan, makamulailah melaksanakan dakwahnya secara diam-diam (sembunyi) sesuai kondisi pada waktu itu. Sasaran dakwah pertama klai yaitu keluarganya sendiri, kerabat dan para shahabatnya. Selanjutnya dengan bantuan Khadijah dan Abu Bakar, bertambah banyak orang yang beriman, dalam masa tiga tahun dakwah pertamanya telah beriman sebanyak 39 orang yang terdiri atas golongan hartawan, hamba sahaya, orang desa, laki-laki dan perempuan.

b. Masa Dakwah (Komunikasi Islam) Secara Terbuka

Setelah melakukan pembinaan terhadap 39 orang yang telah beriman, kemudian turunlah ayat yang menegaskan dakwah secara terbuka, berdasarkan firman Allah swt:

"Maka sampaikanlah olehmu secara terang-terangan segala apa yang telah diperintahkan (kepadamu) dan berpalinglah dari orangorang musyrik". 23

Hal itu dillakukan disebuah tempat dikaki bukit șafa, tetapi Abu Lahab menentang dan mecela Rasulullah saw sehingga dengan peristiwa itu turunlah surat al-Lahab.

${ }^{23}$ Q.S. al-Hijr (15): 94 
c. Masa Dakwah (komunikasi Islam) dengan Risalah (tulisan)

Setelah perdamaian Hudaibiyah pada tahun keempat hijrah, Nabi Muhammad mempraktekan suatu metode dakwah yang ditujukan kepada raja-raja dan kaisar-kaisar, yakni dakwah dengan menggunakan media tulisan, dengan didampingi para shahabar untuk menulis sebagai juru tulis dalam menulis risalah tersebut. Untuk menguatkan surat yang dibuat oleh rasul menggunakan cincin stempel yang terbuat dari perak dan terukirkan tiga baris kalimat "Muhammadan Rasūlullāh". Telah menjadi kebiasaan administrasi masa itu, bahwa surat harus dibubuhi cap pengirim. Risalah Nabi tersebut disampaikan kepada raja Hiraqla (Rum), raja Persi, raja Habsy, raja Qițbi dan lain-lain. ${ }^{24}$

\section{d. Masa Dakwah (Komunikasi Islam) Secara Teoritis}

Dalam sejarah Dakwah Islam, pada masa Abasyiyah Harun alRasyid dan putranya al Makmun mendirikan perpustakaan terbesar dilengkapi dengan translating institue, sebagai pusat pendidikan dan pengetahuan. ${ }^{25}$ Dalam bidang ilmu bahasa ('ilmu al-lughah) berkembang begitu pesat, bahasa arab semakin mendesak membutuhkan ilmu bahasa yang menyeluruh (nahwu, șaraf, alma'ani, al-bayan, al-badi' dan sebaginya). ${ }^{26}$

Dalam perkembangannya, komunikasi dalam Islam yang merupakan hal pokok dalam pelaksanaan dakwah dengan

24. Dr. Hamzah Ya'kub, Publisistik Islam Teknik Dakwah dan Leadership. (Bandung : CV Diponegoro, 1981), h. 54-58, Lihat juga Kustawa. ..., h. 71-78

25 Hasan Ibrahim Hasan,"Tarikh al-Islam", (Kairo: Maktabah al-Nadarah alMișiriyah, 1965), h. 129

${ }^{26}$ Harun Nasution,"Islam Ditinjau dari Berbagai Aspeknya", Jilid II, (Jakarta: UI Press, 1985), h. 14 
Aep Wahyudin, Dakwatologi Komunikasi dan Titik Bias Komunikasi

menggunakan bahasa dan retorika, yang pada selanjutnyaa disebut "fannu al-khitäbah", 27 atau teknik ilmu percakapan. Pada masa selanjutnya, banyak para ilmuwan-ilmuwan muslim yang menulis karya-karya dakwah, diantaranya Muhammad Ahmad al-'Adawi (1935) karyanya “al-Da'wah al-Islamiyah”; Muhammad Ghazali (1961) karyanya “Ma'alahi Dirāsat fi ad-Da'wah wa ad-Du'ah”; Abu Hasan Ali Husaini an-Nadawy (1968) karyanya "Rajālu fikri wa adDa'wah fi al-Isläm"; Muhammad al-Bakry (1970) karyanya "AsSābilu ilā Da'wati al-Haq". Muhammad Abu Zahrah (1973) karyanya " al-Da'wah ilā al-Isläm";

Sayyid Qutub (1976) karyanya "Fiqhu al-Da'wah"; Abdul Karim Zaidan (1976) karyanya “Ușul al-Da'wah". Abdullah Syuahata (1978) karyanya “ad-Da'watu al-Islāmiyah wal-Iklānu al-Dīni”; Ahmad ghalwasyì (1987) "al-Da'wah al-Islämiyah"; Ali Ibn Shalih al-Mursyid (1989) karyanya "Mustalzamāt al-da'wah fi al-'Ashari al Hadir", dan lain-lain. ${ }^{28}$

2. Bentuk Komunikasi Islam Berdasarkan Sasaran dan Konteksnya.

Islam dalam hal ini dipahami sebagai suatu usaha mengkomunikasikan nilai-nilai pesan Ilahiyah dari tatanan deduktif idealistik untuk dibumikan menjadi suatu tatanan induktif realistik. Sasarannya adalah untuk keselamatan hidup manusia seluruhnya (käffatan linnās), ${ }^{29}$ yang memiliki perbedaan realitas sosial, ${ }^{30}$ karena

27 T.A. Lathief Rousydiy, Dasar-dasar Rhetorika Komunikasi dan Informasi, (Jakarta: Rimbaw Medan, 1985), h. 40

28 A. Hasymy, Dustur......., h. 377. Lihat juga Sambas, Ușul.., h. 13, Lihat juga Subandi, Ilmu Dakwah..., h. 181-186

${ }^{29}$ Q.S. Saba' (34): 28 
essensinya Islam berfungsi sebagai rahmat bagi seluruh alam (rahmatan lil'älamin). ${ }^{31}$ Realitas sosial itulah terkait dengan proses dakwah atau komunikasi Islam.

Ruang lingkup dakwah baik dalam bentuk sahșiyah (personal), usrah (komunal), jama'ah (sosial) dan ummat, merupakan perwujudan doktrin Islam dalam seluruh segi kehidupan dalam bentuk realitas tersebut, ${ }^{32}$ guna membentuk khaira ummah. ${ }^{33} \mathrm{Hal}$ ini disadarkan pada ayat Alqurān :

("Hai orang-orang yang beriman, jagalah (lindungilah) dirimu dan keluargamu dari api neraka..."). ${ }^{34}$

"Dan Kami tidak mengutuskamu, melainkan kepada ummat manusia seluruhnya sebagai pembawa (penyampai) berita gembira dan pemberi peringatan..".

Kontekstualisasi dari ayat tersebut, dalam mengkomunikasikan Islam atau proses dakwah Islam kepada realitas masyarakat. Dapat diskemakan dengan struktur sebagai berikut:

\begin{tabular}{|l|c|c|c|c|c|c|}
\hline Rukun & $\begin{array}{c}\text { Da'i } \\
\text { Dakwah } \\
\text { (komunikator) } \\
\text { Dakwahteks }\end{array}$ & $\begin{array}{c}\text { Maudu' } \\
\text { (pesan) }\end{array}$ & $\begin{array}{c}\text { Ușlub } \\
\text { (metode) }\end{array}$ & $\begin{array}{c}\text { Wașa'il } \\
\text { (media) }\end{array}$ & $\begin{array}{c}\text { Mad'u } \\
\text { (komunikan) }\end{array}$ & $\begin{array}{c}\text { Manhaj } \\
\text { (perspektif) }\end{array}$ \\
\hline $\begin{array}{l}\text { Nafstyah } \\
\text { (persona) }\end{array}$ & & & & & & $\begin{array}{c}\text { Istinbat } \\
\text { Iqtibas } \\
\text { Istiqra }\end{array}$ \\
\hline
\end{tabular}

${ }^{30}$ Q.S. al-Hujurāt (49): 13

${ }^{31}$ Q.S. al-Anbiyā (21): 107

${ }^{32}$ Ahmad, Kurikulum...., h. 4

${ }^{33}$ Q.S. ali 'Imrān (3) :110

${ }^{34}$ Q.S. at-Tahrim (66): 6

${ }^{35}$ Q.S. Saba' (34): 28 
Aep Wahyudin, Dakwatologi Komunikasi dan Titik Bias Komunikasi

\begin{tabular}{|c|l|l|l|l|l|l|}
\hline $\begin{array}{c}\text { Fardiyah } \\
\text { (antar } \\
\text { persona) }\end{array}$ & & & & & & \\
\hline $\begin{array}{c}\text { Fi'ah } \\
\text { (kelompok) }\end{array}$ & & & & & & \\
\hline $\begin{array}{c}\text { Hizbiyah } \\
\text { (onganisast) }\end{array}$ & & & & & & \\
\hline $\begin{array}{c}\text { Ummat } \\
\text { (massa) }\end{array}$ & & & & & & \\
\hline $\begin{array}{c}\text { Qaba'llyah } \\
\text { (Antar } \\
\text { budaya) }\end{array}$ & & & & & & \\
\hline $\begin{array}{c}\text { Shu'ublyah } \\
\text { (Antar } \\
\text { bangsa) }\end{array}$ & & & & & & \\
\hline
\end{tabular}

Sumber : Disarikan dan dipolarisasikan dari uṣul al-ithnā al-'ash'ariyāh (matan wilayah kajian dakwah) ${ }^{36}$

Keterangan :

Istinbat : Proses penalaran (istidāâ) dalam memahami dan menjelaskan hakikat dakwah dari Alqurān dan Alhadith yang produknya sebagai teori utama dakwah (grand theory)

Iqtibas : Proses penalaran (istida) dalam memahami dan menjelaskan hakikat dakwah dengan mengambil pelajaran dari teori ilmuilmu sosial (Midle Theory)

Istiqrā : Proses penalaran (istịda) dalam memahami dan menjelaskan hakikat dakwah melalui penelitian kualitatif dan kuantitatif dengan mengacu pada teori produk istinbath dan iqtibas (lower theory).

${ }^{36}$ Dalam Sambas, Ushul..., h 3 dan 6 


\section{B. Tujuan Komunikasi Islam dan Konsekwensi Penyimpangan}

Tujuan sentral komunikasi, menurut R. Wayne Pace, Brent D. Peterson, dan M. Dallas Burnett dalam "Techques for Effective Communication", menyebutkan :

- to secure understanding (mengerti pesan yang diterimanya)

- to established acceptence (penerimanya harus dibina)

- to motivate action (kegiatan dimotivasikan) ${ }^{37}$

Tujuan tersebut dalam kaitannya dengan Islam, memunculkan nilai-nilai religiusitas yaitu akhlaq atau etika dalam komunikasi. Etika muncul sebagai sebuah tema sosial dalam kaitannya dengan religiusitas manusia yang memiliki keyakinan teologis. Dimensi akhlaq sebagai suatu antisipasi penyebab konflik, dari komunikasi yang destruktif dan immoral. ${ }^{38}$ Oleh karenanya akhlaq sebagai suatu etika merupakan sistem dalam makna kesusilaan dan kepatutan prilaku manusia dalam masyarakat, dengan sistem itu yang baik dan yang buruk serta ucapan manusia diperiksa menurut takaran kesusilaan dan kepatutan. ${ }^{39}$

Maka tujuan komunikasi dalam Islam ada dua hal, pertama : tujuan secara shari'ät (formal); menyampaikan pesan dengan berakhlaq merupakan pokok dari Islam, karena memang Nabi diutus untuk menyempurnakan akhlaq (innamã bu'ithtu li utammima makärima alakhlāq). Alqurān menegaskan perintah menyeru kebaikan, ${ }^{40}$ berlaku

${ }^{37}$ Effendi, Ilmu Komunikasi...., h. 32

38 Solatun, Islam dan Etika Komunikasi : Studi Interpretatif tentang pendekatan Etis dalam Komunikasi antar Ummat Berbeda agama menurut Studi Pandang Islam Tekstual, Tesis, (Bandung: UNPAD, 1999), h. 20

${ }^{39}$ Ensiklopedi Indoensia, Edisi Khusus, (Jakarta: Ikhtiar Baru Van Hove, 1981)

${ }^{40}$ Q.S. ali 'Imrān (3): 104, 110 
Aep Wahyudin, Dakwatologi Komunikasi dan Titik Bias Komunikasi

lemah lembut kepada mad'u (komunikan, sasaran), ${ }^{41}$ Allah tak menyukai kata-kata kasar, ${ }^{42}$ berbicara dengan kalimat yang damai, ${ }^{43}$ Berbantah dengan cara yang baik, ${ }^{44}$ berbantah dengan musuh dengan cara baik seperti sahabat, ${ }^{45}$ membalas dengan lebih baik penghormatan, ${ }^{46}$ mengajak dengan hikmah (kebijaksanaan), ${ }^{47}$ tolak kejahatan dengan cara yang baik, ${ }^{48}$ dan ayat-ayat lain yang serupa, yang dalam dalam Alqurān menggunakan term-term qaulan layyinā, ${ }^{49}$ qaulan karimā, Qaulan maysūrā, ${ }^{50}$ qaulan thaqilāa, ${ }^{51}$ qaulan ma'rūfā́ ${ }^{-52}$, qaulan balighā, ${ }^{53}$ qaulan shadidä, ${ }^{54}$ (perkataan yang lembut, mulia, mudah, berbobot, baik, yang tersampaikan) dan sebaginya. Sebagaimana digambarkan dalam suatu riwayat, oleh Abu Sofyan ketika menceritakan pertemuannya dengan raja Hiraqlius yang bertanya kepada Abu Sofyan: "Nabi itu (Muhammad saw.) menyuruh apa kepadamu? Maka Abu Sofyan menjawab: "Sembahlah Allah dan jangan menyekutukan Dia dengan sesuatu

\footnotetext{
${ }^{41}$ Q.S. ali 'Imrän (3): 159

${ }^{42}$ Q.S. an-Nisā' (4): 148

43 Q.S. al-Furqān (25): 63

${ }^{44}$ Q.S. an-Nahl (6); 125; al-Ankabut (29): 46

${ }^{45}$ Q.S. Fușsilat (41): 34

${ }^{46}$ Q.S. an-Nisā' (4): 86

${ }^{47}$ Q.S. an-Nahl (16): 125

${ }^{48}$ Q.S al-Mu'minūn (23) : 96

${ }^{49}$ Q.S. Taha (20): 44

${ }^{50}$ Q.S. al-Isrä' (17): 28

${ }^{51}$ Q.S. al-Muzammil (73): 5

${ }^{52}$ Q.S. an-Nisā' (4): 5

${ }^{53}$ Q.S. an-Nisā' (4): 63

${ }^{54}$ Q.S. an-Nisā' (4): 9, al-Aḥzāb (33): 70;
} 
pun....., berkata benar, sopan (pemaaf), dan menjalin hubungan atau wasilah"..$^{55}$

Kedua; tujuan secara hakikat (substansia), adalah untuk menanamkan keyakinan, menumbuhkan sikap dan mendorong prilaku manusia menurut nilai-nilai dan ajaran Islam untuk menjadikan kenyataan dalam kehidupan. ${ }^{56}$ Juga bertujuan terwujudnya khairul ummah (ummat yang terbaik) ${ }^{57}$ yang basisnya didukung oleh muslim yang berkualitas khairul barriyah $h^{58}$ (insan terbaik) yang oleh Allah dijanjikan memperoleh ridlo-Nya.

Pada dasarnya, apabila sudah dilaksanakan dakwah atau mengkomunikasikan Islam secara optimal, namun kurang berhasil, maka secara teologis hal itu tidak apa-apa. Hal ini didasarkan pada ayat:

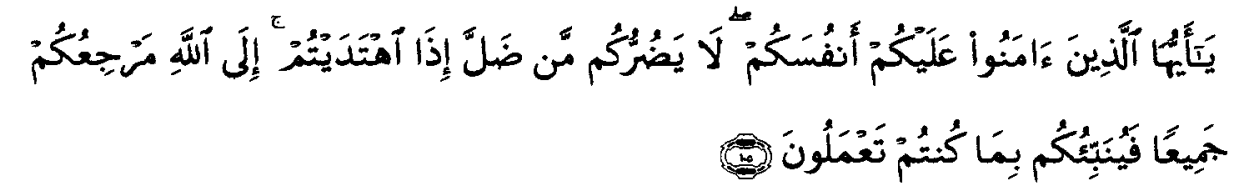

("...Tidaklah orang yang sesat itu akan memberi mudlarat kepadamu apabila kamu telah mendapat petunjuk, kepada Allahlah kamu kembali semuanya.."). ${ }^{59}$

Akan tetapi jika terjadi penyimpangan dari tujuan tersebut, secara teologis hal itu telah keluar dari koridor syari' at dan mardlatillah, firmanNya menegaskan: "Amat besar kemurkaan di sisi Allah bahwa kamu

${ }^{55}$ Syarifuddin An-Nawawy, Matan Al- 'Arba'in, (Jakarta: Al-Ṭahiriyah. Jild I, 1384 H-1985), h. 78

${ }^{56}$ Zaini Muhtarom, Dasar-dasar Manajemen Dakwah, (Yogyakarta: Al-Amin. 1996), h. 14

${ }^{57}$ Q.S. ali 'Imrān (3): 110

${ }^{58}$ Q.S. al- Bayyinah (98): 7

${ }^{59}$ Q.S. al-Mā'idah (5): 105 
berkata apa yang tidak kamu perbuat". 60 Pandangan etis teologis telah tereliminir, dengan tidak memiliki aspek transendenlisme dalam tindakannya. Dan secara akademis, penyimpangan dari tujuan terjadi karena menafikan profesionalitas dan proporsionalitas. Konsekwensi sosial dari hal ini akan terjadi diskomunikasi bukan harmonisasi komunikasi, dissosialisasi bukan sosialisasi, alienasi komunikasi, dan sebagainya.

\section{Predudice Dalam Komunikasi Dan Antisipasinya Menurut Komunikasi Islam}

Pre-judice atau prasangka, merupakan unsur emosi yang memiliki keterkaitan dengan daya tarik motif, kekuatan daya tarik motif ditentukan oleh kekuatan emosi yang mewarnainya. ${ }^{61}$ Emosi prasangka merupakan kebencian yang subjektif, karena telah beraapriori terlebih dahulu dengan konotasi dan citra negatif (negative immage). Prasangka berhubungan langsung dengan ethos, yang merupakan sikap seorang komunikator dalam kata-kata dan prilakunya, mengandung perpaduan antara keahlian, kebenaran, ke'arifan, timbang rasa dan tenggang rasa. ${ }^{62}$ Oleh karenanya, adanya prasangka (pre-judice) akan menghambat efektivitas komunikasi, karena salah satu pendekatan agar komunikasi efektif, menurut B. Aubrey Fisher (1986) harus adanya penyesuaian antara komunikator dan komunikan. ${ }^{63} \mathrm{Hal}$ ini timbul, prasangka dari sisi

\footnotetext{
${ }^{60}$ Q.S. as-Șaff (61): 3

${ }^{61}$ Jalaluddin Rakhmat, Rethorika Modern: Pendekatan Praktis, (Bandung: Rosdakarya, 1994), h. 106

${ }^{62}$ Onong Uchyana Effendi, Kamus Komunikasi, (Bandung: Mandar Maju, 1989), h. 121

${ }^{63}$ B. Aubrey, Teori-teori Komunikasi, Penyunting; Jalaluddin Rakhmat, (Bandung: Rosdakarya, 1986)
} 
komunikan yang melihatnya. Oleh karenanya dalam ajaran Islam prasangka (pre-judice) - negative thinking, adalah bentuk sifat su'uzan (buruk sangka). Sifat dan sikap seperti ini, merupakan syak wasangka yang secara sengaja mencari kesalahan-kesalahan orang lain, dan tidak dibenarkan dalam Islam, ayat Alqurän menegaskan :

("Hai orang-orang yang beriman, jauhilah dari kebanyakan prasangka, sesungguhnya sebahagian prasangka itu adalah dosa dan janganlah kamu mencari-cari kesalahan orang lain dan janganlah kamu sebahagian kamu menggunjing sebagian yang lain ...").

Untuk mengantisipasi dari bentuk prasangka ini, yang menghambat terjadinya komunikasi yang effektif, bahkan terjalinnya hubungan sosial (relationship) yang baik. Maka, dalam tinjauan Islam dapat dilakukan beberapa bentuk antisipasi :

\section{Antisipasi pada Komunikator}

Menghadapi orang yang berprasangka dalam konteks komunikasi ini, bukan menentang dengan berbalik prasangka lagi, dinyatakan dalam Alqurān: "Dan bersabarlah terhadap apa yang mereka ucapkan dan jauhilah mereka dengan cara yang baik." ${ }^{\circ 5}$ Antisipasi yang ditekankan pada komunikator adalah membangun kredibilitas selaku penyampai pesan (message). Hovland dan Weiss menyatakan bahwa "credibility" terdiri dari dua unsur: expertise (keahlian) dan trustworthiness (dapat dipercaya). ${ }^{66}$ Aritoteles menyebut karakter komunikator ini sebagai ethos, ethos terdiri dari pikiran baik, akhlaq yang baik, dan maksud yang baik (good sense, good moral character,

${ }^{64}$ Q.S. al-Hujurāt (49): 12

${ }^{65}$ Q.S. al-Muzammil (73): 10

${ }^{66}$ Jalaluddin Rakhmat, Psikologi Komunikasi, (Bandung: Rosda Karya, 1996), h. 
Aep Wahyudin, Dakwatologi Komunikasi dan Titik Bias Komunikasi

good will). ${ }^{67}$ Citra diri pada komunikator adalah akhlaq al-karimah dengan pembuktian amal șaleh, sebagaimana dinyatakan Alqurān: "Siapakah yang lebih baik perkataannya daripada orang yang menyeru kepada Allah, mengerjakan amal yang shaleh dan berkata: sesungguhnya aku termasuk orang-rang yang menyerahkan dir"' 68

\section{Antisipasi pada Komunikan}

"Unzur mā qāla walā tanzur man qālà" (lihatlah apa (isi) yang dikatakanya, dan tidaklah melihat orang yang mengatakannya). Dari ungkapan keterangan tersebut, mengindikasikan akan urgensitas informasi terlepas dari siapa yang mengatakannya. Dan membangun pandangan yang positif atau "ḥusnuzāan" kepada orang lain, tidak terjebak dalam pancingan situasi emosional, dan emosi merupakan salah satu faktor yang mempengaruhi pemecahan masalah dalam komunikasi, ia akan mempengaruhi cara berpikir dan tidak pernah berpikir objektif. ${ }^{69}$

Komunikasi yang diawali dengan positif thinking (husnuzān), akan ada keterbukaan, menurut Devito (1978) faktor keterbukaan penting dalam komunikasi, empati, perasaan positif, dukungan dan keseimbangan. ${ }^{70}$

${ }^{67}$ Ibid., h. 255

${ }^{68}$ Q.S. Fusșilat (41): 31

${ }^{69}$ Rakhmat., Psikologi... h. 74

${ }^{70}$ A. Devito, Recognizing and Assesing Creativity, In Jweigand ed. "Development Teacher Competenties", (New Jersey: Prentic Hall Inc. 1978), p. 261. Lihat juga, Rakhmat, Psykologi...h. 120 


\section{Kredibiltas Sumber Dalam Komunikasi Perspektif Islam}

Sumber (informasi) dalam Islam merupakan hal penting, karena komunikasi tanpa memperhatikan sumber menyesatkan. Islam memerintahkan berkata tentang kebenaran dan kebaikan, sebagaimana hadits menyatakan: "Man käna yu'minu billāhi wa al-yaumil äkhiri fal yaqul khairun au liyașmuf' (barang siapa beriman kepada Allah dan hari akhir maka berkatalah yang baik atau diam)." "71 Islam melarang informasi yang tak didasarkan kebenaran (kebohongan informasi). ${ }^{72}$ Oleh karenanya informasi yang diterima harus didasarkan pada ketelitian alsam'a (pendengaran), al-abșar (penglihatan), dan al-fu'ad (akal-hati), sebab kesemuanya memiliki konsekwensi teologis. ${ }^{73}$ Dalam ajaran Islam, Alqur'an menyebutnya harus ada "tabayyun" (penjelasan), ${ }^{74}$ sebagai berikut :

$$
\text { با ايهالنين امنوا ان جاءكم فلسن بنباء فتبينوا }
$$

("Hai orang-orang yang beriman, jika datang kepadamu orang fasiq membawa suau berita maka periksalah dengan teliti..."). ${ }^{75}$

Sebagian orang Kuffah, dan umumnya orang Madinah, membaca

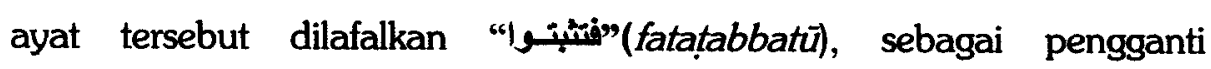
"فتبينوا"(fatabayyanü). Menurut Ibnu Jarir keduanya berarti mencari kepastian dan kejelasan dengan dalil atau bukti. Mencari ketetapan dari

\footnotetext{
${ }^{71}$ Habib Abdullah Hadad, Al-Naṣa' ih al-Diniyah wa al-Wașaya al-Imāmah, terj. "Nasihat agama dan Wasiat Iman", (Bandung: Gema Risalah Press, 1993), h. 389

${ }^{72}$ Q.S. Ali 'Imrān (4): 6, 105

${ }^{73}$ Q.S. al-Isrä' (17): 36

${ }^{74}$ Dr. Sayyid Muhammad Nuh, Affatun 'Alā At-Tariq, terj. "Terapi Mental Aktivis Harakah", (Solo: CV. Pustaka Mantik. 1995), h. 344-345

${ }^{75}$ Q.S. al Hujurat (49): 6, Q.S. an-Nisā' (4): 94
} 
suatu hakikat, bisa menjadi jelas dan terbuka keadaannya. ${ }^{76}$ Ayat ini memperingatkan kepada ummat Islam untuk selalu tidak menerima dari sebelah fihak saja. ${ }^{77}$

\section{E. Komunikasi Persuasi (Makna, Motif, Daya Tarik) Perspektif Komunikasi islam}

Komunikasi yang dilakukan secara persuasi, sarat dengan isi yang mengandung suatu makna, motif, dan daya tarik (membuat orang ingin berbuat). Pada dasarnya dalam dakwah hal ini berkaitan dengan al hikmah (kebaijaksanaan), yang hal itu dapat dipahami, sebagai berikut :

${ }^{76}$ Nuh, Affatun...., H. 345
${ }^{77}$ Dr. H.M.D. Dahlan, et. al, Asbäbun Nuzül, (Bandung : CV. Diponegoro, 1995) h. 470. Sebab turunnya ayat ini adalah, diriwayatkan bahwa al-Harth menghadap Rasulullah, beliau mengajak kepadanya untuk masuk Islam. Rasul mengajaknya untk mengluarkan zakat, dan ia menerimanya, ia berkata : Yã Rasulullah aku akan pulang ke kaumku untuk mengajak mereka masuk Islam dan menunaikan zakat. Barang siapa yang mengikuti ajakanku akau kukumpulkan zakatnya. Apabila telah sampai waktunya kirimlah utusan untuk mengambil zakat yang telah kukumpulkan. al-Harth berhasil mengumpulkan zakat, dan menunggu utusan Rasulullah karena sudah tiba waktunya, tapi utusan tidak datang juga, ia mengira rasul marah. Padahal rasul telah mengutus al-Walid, namun ia merasa gentar dan takut, sehingga pulang lagi dan berkata kepada rasul (laporan palsu) bahwa al-Harth tidak mengumpulkan menyerahkan zakat, bahkan ia akan membunuhnya.

Kemudia Rasulullah mengutus utusan berikunya beserta para shahabat yang bertemu dengan al-Harth di perjalanan, shahabat itu menceritakan bahwa rasul telah mengutus kepada al-Walid, namun al-Harts tidak menyerahkan zakat bahkan akan membunuhnya. Al-Harts Berkata :" Demi Allah yang telah mengutus Muhammad, aku tidak melihatnya, dan tak ada yang datang kepadaku".

Ketika sampai kehadapan Rasulullah, ia bertanya :"mengapa engkau menahan zakat dan hendak membunuh utusanku? al-Harth menjawa :"Demi Aallah yang telah mengutus engkau, aku tidak berbuat demikian. (Diriwayatkan oleh Ahmad dan lainnya dengan sanad yang baik bersumber dari al-Harth Bin Dirāra al-Khuzā'i, sanad rawi-rawi hadith ini sangat bisa dipercaya). 
1. Komunikasi Persuasi: Dakwah sebagai Motivasi dan Tidak ada Paksaan dalam Islam.

Komunikasi persuasi artinya membujuk, mengajak, atu merayu yang bertujuan untuk mengubah sikap, pendapat dan perilaku. ${ }^{78}$ Sebagai hasilnya fihak yang dipengaruhi melaksanakannya dengan kesadaran. ${ }^{79}$ Islam sebagai agama dakwah dan Alqurān sebagai kitab dakwah, ${ }^{80}$ menyatakan tidak ada unsur paksaan dalam (masuk) Islam, ${ }^{81}$ dalam mengajak kepada al-khair (al-Islām). ${ }^{82}$ Syekh Abdurrahman Abdul Khaliq (1996), mengatakan Islam sebagai agama motivasi, karena setiap muslim diwajibkan untuk menyeru (berdakwah) kepada al-Islām sesuai dengan kemampuan masingmasing yang dimiliki. ${ }^{83}$

2. Dakwah dengan Al-Hikmah: Dari Kesadaran Kognisi ke Kesadaran Konasi.

Al-Hikmah merupakan kebijaksanaan yang meliputi cara dan taktik dakwah, yang dperlukan dalam menghadapi golongan manapun. Hikmah juga berarti perkataan yang jelas dan tegas, disertai dengan dalil-dalil yang dapat memperjelas kebenaran dan

${ }^{78}$ Onong Uchyana Effendi, Dinamika Komunikasi, (Bandung : Roasda karya. 1993), h. 21

${ }^{79}$ Effendi, Kamus., h. 270

80 Sayyid Qutub, Fiqhu al-Da'wah, "Maudu'at fi al-Da'wah wa al-Harakah". (Bairut : Mu'assasah al Risalah 1970), h. 15

${ }^{81}$ Q.S. al-Baqarah (2): 256

${ }^{82}$ Q.S. Ali 'Imrān (3): 104

${ }^{83}$ Abdurrahman Abdul Khaliq, Fusūlun min al-Shiyasāti Shar'iayti fi Da'wati ilà Alläh" terj. "Metode dan Strategi Dakwah Islam", (Jakarta: Pustaka Al-Kauthar, 1996), h. 17 
menghilangkan keraguan. ${ }^{84}$ al-Fairuz Abady dalam "Baṣā'iru Zawit Tamyiz", menguraikan al hikmah dengan keadilan, ilmu, kelembutan, nubuwah, taat kepada Allah, pemahaman aga secara mendalam dan pengamalannya, rasa takut, wara' akal,, ketetapan dalam bicara atau perbuatan, memikirkan perintah Allah dan mengikutinya. ${ }^{85}$ Jadi pokok al hikmah dalam dakwah ialah membimbing kepada kebaikan yang didasarkan pada ilmu pengetahuan untuk mencegah perbuatan zhalim. ${ }^{86}$ Karakteristik Islam adalah paralel dengan akan fikiran yang sehat menyadari dengan sebenar-benamya, bahwa pemaksaan dalam suatu agama, akan melahirkan kepalsuan keyakinan dan hipokritis teologis. ${ }^{87}$

Aspek kesadaran pemahaman kognisi dalam proses dakwah, dilakukan dengan cara tabligh. Termasuk dalam kerangka tabligh ini bentuk da'wah bi lisän (dakwah dengan lisan), dan kegiatan tabligh Islam ini merupakan proses transmisi atau penyiaran dan penerangan sosialisasi ajaran Islam dengan menggunakan sarana tertentu. $^{88}$ Karena tabligh secara kebahasaan, menurut Louis Makluf berarti penyampaian sampai kepada sesuatu yang dikehendaki, ${ }^{89}$ dan J. Milton Cowan (1971) menyatakan sebagai komunikasi, maklumat,

\footnotetext{
${ }^{84}$ M. Natsir, Fiqhu Da'wah, (Dewan Dakwah islam Indonesia, 1984), h.165

${ }^{85}$ Mujiduddin Muhammad Bin Ya'kub Al-Fairuz Al-Abady, Bașa'iru Zawit Tamyiz fi Lata'ifi al Kitäbi al-Aziz, (Bairut: Al-Maktabah al-'Ilmiyah,Tth.), h. 491

${ }^{86}$ Dr. Zaid Abdul Karim Az Zaid, al-Hikmah fi al-Da'wah ilā Allāh, terj. (Dakwah bil hikmah), Oleh Kathur Suhardi, (Jakarta: Pustaka Al-Kauthar, 1993), h. 16

${ }^{87}$ Ya'kub, Publisistik...., h. 68

${ }^{88}$ Ahmad, Kurikulum...., h. 6

${ }^{89}$ Louis Makluf, Al-Munid fi al-Lughah wa al-'Adab, (Bairut: Matba'ah Kastulkiyyah, Tth.), h. 48
} 
atau pemberitaan. ${ }^{90}$ Dalam konteks dakwah, penyampaian tersebut adalah mengenai ajaran Islam kepada ummat manusia, sehingga yang mnerima menjadi terikat dengannya, ${ }^{91}$ sebab Alqurān memerintahkan atas wahyu (iformasi pesan Ihaiyah) harus disampaikan. ${ }^{92}$

Keterikatan atas dasar kesadaran konasi, menjadi nilai-nilai prilaku nyata, dilakkukan dengan bentuk da'wah bi al-hāl. Dakwah ini dilakukan qudwah atau uswah hasanah (tauladan) sikap dan perilaku, yang secara efektivitas lebih daripada bicara. Qudwah dalam dakwah bi al-hal ini yang penting direalisasikan' khususnya pada qudwah 'amaliyah (keteladanan dalam amal), ${ }^{93}$ sebab dakwah merupakan ajakan keinsyafan. ${ }^{94}$ Alqurān tegas mengecam inkonsistensi ucapan dengan perbuatan, ${ }^{95}$ karena teologis keimanan manusia perlu pembuktian pada sosial dan amal shaleh. ${ }^{96}$

Komunikasi persuasi tersebut, dapat dikerangkakan dalam pola pemahaman dakwah, sebagai berikut :

${ }^{90}$ J. Milton Cowan, A Dictionary of Written Arabic, (London : Goerge Allan and Unwin, 1971), h. 74.

${ }^{91}$ Subandi, Ilmu..., h. 34.

${ }^{92}$ Q.S. ali 'Imrān (3): 34, al-Ahquäf (46): 23

${ }^{93}$ Al Ustadz Mushtafa Masyhur, Qudwah 'alā Tariqi al-Da'wah, terj. (Qudwah di Jalan Dakwah). Oleh Miqdad Haqqani, (Solo: Citra Islami Press, 1996), h. 9

${ }^{94}$ M. Qurais Shihab, Membumikan Alqurān, (Bandung: Mizan, 1995), h. 194

${ }^{95}$ Q.S. aș- Șaff (61): 2-3

${ }^{96}$ Q.S. al-Bayyinah (98) : 7 


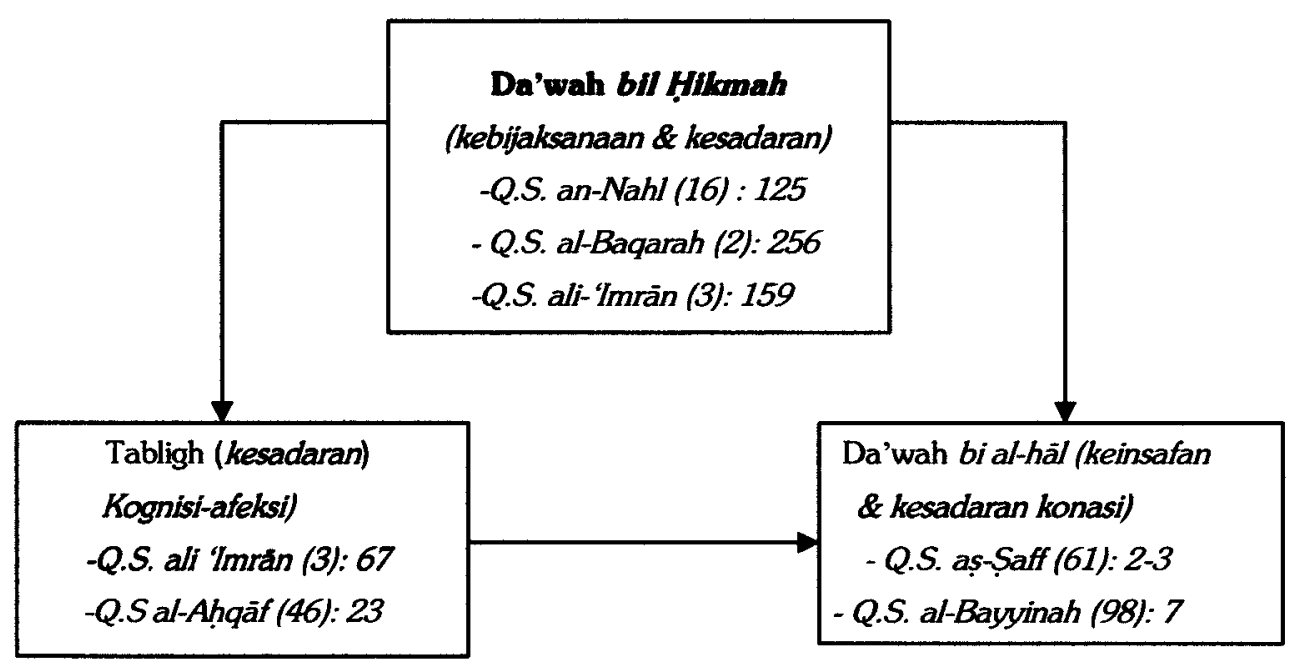

\section{F. Psikologi komunikan (Behaviorisme, Psiko-analitik, Psiko- kognitif dan Humanistik) Dalam Pandangan Islam}

Allah memberikan memposisikan keterwakilan terhadap manusia (sebagai subjek dan objek dakwah), menjadikan khalifah fil ard (pemimpin di muka bumi), ${ }^{97}$ secara psikologis maupun biologis mengindikasikan pengarhargaan terhadap eksistensi manusia dalam bentuk sempurna ${ }^{98}$. Ketegasan psikologis manusia pun, dinyatakan bahwa dalam Islam tak ada unsur paksaan, ${ }^{99}$ hal ini dipahami adanya iklim demokratis kebebasan manusia. Dan Islam sebagai ajaran untuk ummat manusia, ${ }^{100}$ menegaskan pengamalan ajaran tersebut berdasarkan kemampuan, ayat Alqurān menyatakan: "lā yukallifu Allāha

\footnotetext{
${ }^{97}$ Q.S. al-Baqarah (2): 30

${ }^{98}$ Q.S. at-Tịn (95): 4

${ }^{99}$ Q.S. al-Baqarah (2): 256

${ }^{100}$ Q.S. Saba' (34): 28
} 
illā wus'aha" (Allah tidak membebani seseorang melainkan sesuai dengan kemampuannya), ${ }^{101}$ karena Islam memberikan kemudahan bukan membuat kesusahan (inna Allāha yurídu bikumul yusrā walā yuridu bikumul 'usrā).

Psikologi manusia sebagai komunikan, yang dipahami dalam behaviorisme, psiko analitik, psiko kognitif dan humanistik. Tidak dipahami dalam kerangka filsafat dengan paradigma pemikiran modern yang antromorfik dan sekuler. ${ }^{102}$ Karena pandangan yang humanis antroposentris plus sekularis merupakan penjelmaan rasionalitas manusia modern, akan melupakan "siapakah ia sesungguhnya", karena ia hidup di feri-feri (pinggiran) eksistensi. ${ }^{103}$ Dengan kata lain tanpa bantuan wahyu, yang merupakan dasar agama, tabi'at insai sudah dapat mengusakan karya budinya, ${ }^{104}$ sebuah keterpisahan dari yang transenden.

Islam dalam konteks dakwah, melihat psikologi komunikan dalam pola pemahaman behaviorisme, psiko analitik, psiko kognitif dan humanistik, tetap frame utama transendetalisme. Immanuel Kant (17241804), menyebut metode dan model pendekatan filsafat ilmu yaitu kritisisme, yang didalamnya terdapat istilah "transendental". 105 Meminjam istilah M. Amin Abdullah, tetap memiliki dimensi etis teologis Pustaka, 1994), h. 98

${ }^{101}$ Q.S. al-Baqarah (2): 286

${ }^{102}$ Seyyed Hossein Nasr, Islam Tradisi Dikancah Dunia modern, (Bandung:

${ }^{103}$ Sayyed Hossein Nasr, Sains dan Peradaban dalam Islam, (Bandung: Pustaka . 1985), h. 18

${ }^{104}$ Harun Hadi Wijono, Sari-sari Sejarah Filsafat Barat, (Jakarta: Kanisius, 1994), h. 12

${ }^{105}$ Sukriadi Sambas, Transendetalisme: Suatu Bagian dari Metode Ilmiah, Dalam Mimabr Studi, No. 72/xvii/September, (Bandung: IAIN SGD, 1995), h. 10 
Aep Wahyudin, Dakwatologi Komunikasi dan Titik Bias Komunikasi

dan dimensi etis antropologis. ${ }^{106}$ Oleh karenanya dalam hal ini, perspektif Islam dalam konteks dakwah tetap memperhatikan psikologi manusia sebagai komunikan, diungkapkan dalam hadits riwayat Muslim: "khäthibinnās 'alā qadri 'uqulihim' (berbicaralah kepada manusia menurut akal kemampuan mereka) ${ }^{107}$. Dapat digambarkan:

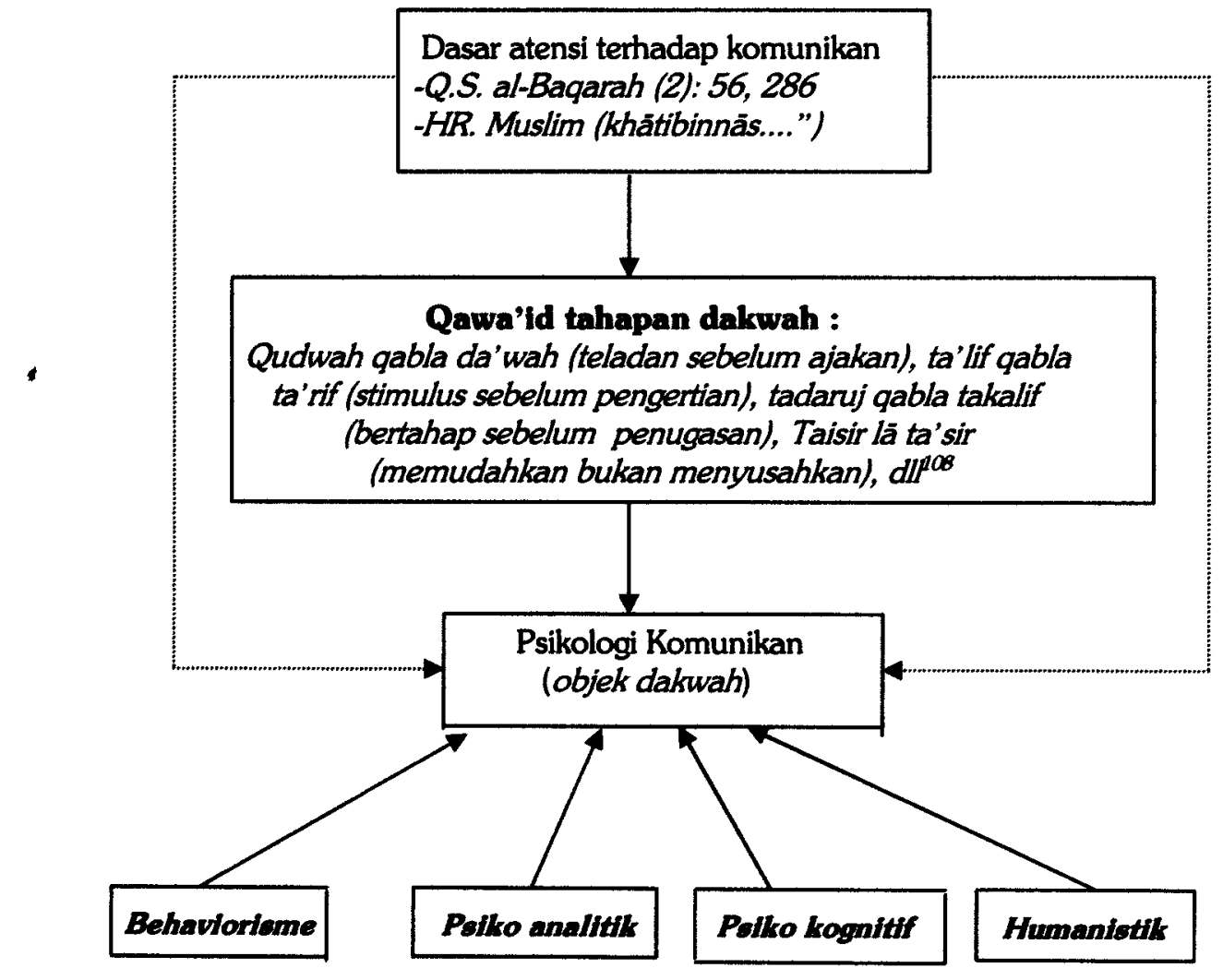

${ }^{106}$ M. Amin Abdullah, Falsafah Kalam Di Era Pots Modernisme, (Yogyakarta: Pustaka Pelajar, 1995), h. 177

${ }^{107}$ Subandi, Ilmu..., h. 109

108 Menurut Jum'ah Amin Abdul Aziz, Istinbat Qawā'id min al-Ușul Tarshudu alDa'i, Dalam Catatan Kuliah Strata Satu Fakultas Dakwah, (Bandung: IAIN SGD, T. th.), T.h. 


\section{G.Teknik Komunikasi Informatif, Persuasif, Koersif dan Manifulatif Menurut Islam.}

Islam dalam pengertian dakwah, sebagai proses transmisi, transformasi, insternalisasi, sosialisasi, dan eksternalisasi pesan-pesan kewahyu-an, untuk di dipahami, dihayati, diamalkan, dan dilembagakan yang dikontekstualisasikan dalam prilaku sosio-kultural kehidupan manusia. Dari pengertian substansial ini, memiliki titik sinkronistik secara operasional dengan teknik komunikasi berupa informatif, persuasif, koersif dan manipulatif (dalam pengertian rekayasa positif), dalam proses mengkomunikasikan pesan-pesan Islam untuk dibumikan.

Teknik komunikasi berupa informatif, dipahami dalam Islam (dakwah) sebagai proses tabligh, ${ }^{109}$ yaitu transmisi dan penyebarluasan ajaran Islam. ${ }^{110}$ Teknik komunikasi persuasi, dalam konteks dakwah sebagai proses irshad, yaitu internalisasi dan bimbingan nilai-nilai Islam, ${ }^{111}$ dan juga berarti mau'izah hasana $h^{112}$ atau nasihat dan tutur kata yang baik. ${ }^{113}$ Komunikasi dengan teknik koersif, mengandung pengertian tandhir, ${ }^{114}$ yaitu merupakan peringatan, atau juga dalam arti ikhtisab, sebagai proses dakwah 'amar ma'rüf nahy munkār. ${ }^{115}$ Dan teknik komunikasi berupa manipulatif (dalam pengertian positif), dalam konteks dakwah diidentifikasi dengan tahsin (membaguskan), yaitu sebagai suatu

${ }^{109}$ Q.S. ali 'Imrān (3): 67, Q.S. Qāf (50): 23

${ }^{110}$ Sambas, Ușul..., h. 2; Lihat juga dalam Subandi, Ilmu..., h. 34; Ahmad, Kurikulum..., h. 6

${ }^{111}$ lbid.

112 Q.S. an-Nahl (16): 125

113 Subandi, Ibid. hal 96. Lihat Juga Syamsuri Siddiq, Da'wah dan teknik Berkhutbah, Bandung: PT. Al-Ma'arif, 1981), h. 27

${ }^{114}$ Jamaluddin Kafie, Psikologi Dakwah, (Surabaya: Ofsett Indah, 1993), h. 39;

Q.S. At-Taubah (9): 22

${ }^{115}$ Subandi, Ilmu..., h. 22 
teknik dan cara membuat indah, dengan upaya agar metode dan pesan komunikasi Islam yang dilakukan memiliki daya tarik. Tuhan memiliki nama-nama yang paling indah, ${ }^{116}$ la menciptakan segala sesuatu dengan keindahan, ${ }^{117}$ dan menurunkan risalah yang paling indah dalam bentuk kitab. ${ }^{118}$ Teknik komunikasi tersebut dapat digambarkan:

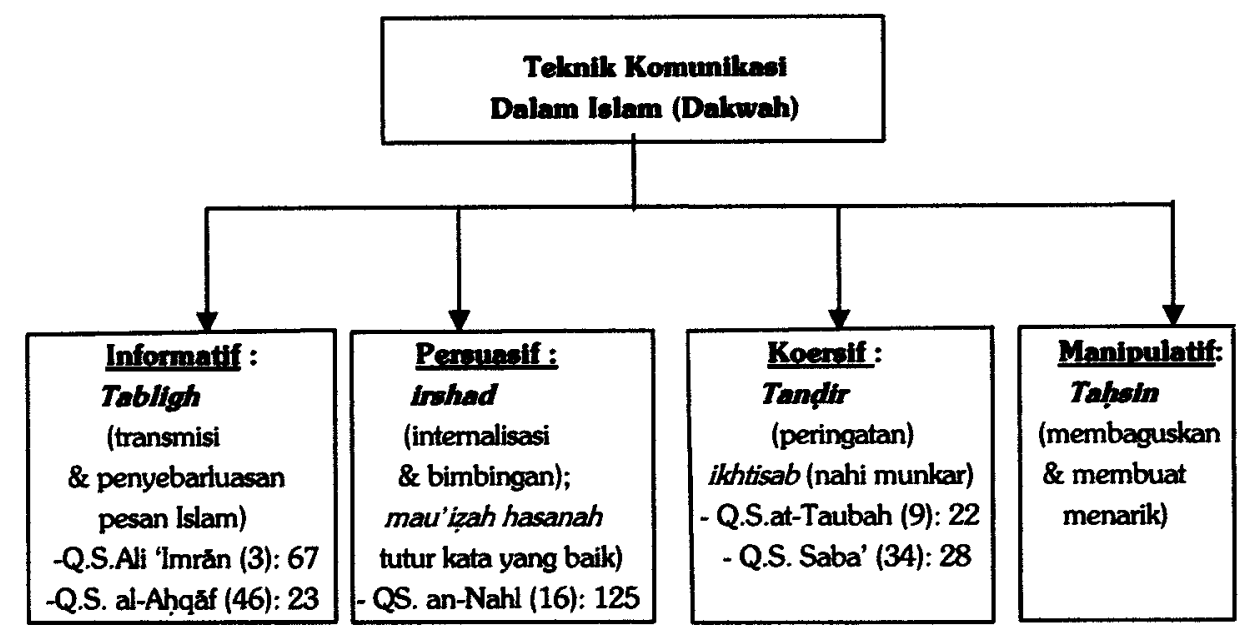

H. Komunikasi Dengan Alam Sekitar (Universe) Menurut Islam: Urgensi Komunikasi dengan Alam dan Alam (kawniyah) sebagai Sumber Daya

Tuhan menciptakan pedoman bagi ummat manusia terdiri dari : ayat-ayat qur'āniyah (kitabullah secara tekstual), dan ayat-ayat kawniyah (alam semesta secara kontekstual). Alqurān sebagai kitab yang bersifat "mujmali" (universal) ${ }^{119}$ mengandung pesan-pesan kehidupan. Antara lain menyangkut alam raya dan fenomenanya, uraian mengenai ayat-

${ }^{116}$ Q.S. al-A'rāf (7): 180; al-lsrä' (17): 110; Ṭaha (20): 8

${ }^{117}$ Q.S. as-Sajadah (32): 7

${ }^{118}$ Q.S. az-Zumar (39): 55

${ }^{119}$ Q.S. an-Nahl (16): 84 
ayat kawniyah tersebut tidak kurang dari 750 ayat, baik yang eksplisit maupun yang tersirat. ${ }^{120}$ Alqurān memproklamirkan dirinya sebagai "hudan linnās"(petunjuk bagi ummat manusia), bukan hanya masalah praksis kehidupan manusia, tetapi juga tentang patokan-patokan dasar tentang bagaimana manusia menyantuni alam semesta dan lingkungannya. ${ }^{121}$ Dalam Islam alam bukan saja sebagai amanah ${ }^{122}$ tapi juga memiliki anugerah potensi sumberdaya. Maka posisi manusia, dalam melakukan komunikasi dengan alam sekitar (universe), menurut Islam mengandung makna sebagai :

\section{Istiqra: Studi Eksplorasi (Penelitian dan pengamatan)}

Kandungan mendalam falsafah "iqra" sebagai kata pertama dari wahyu pertama yang diterima Nabi Muhammad saw, mengandung arti perintah baca. Secara umum, ini pun ditujukan untuk ummat manusia, karena realisasi perintah tersebut merupakan kunci pembuka jalan kebahagiaan hidup dunia dan akhirat. ${ }^{123}$ Dalam kamus-kamus bahasa, iqra' bisa berarti menyampaikan, menela'ah, membaca, memdalami, meneliti, mengetahui ciri-cininya, dan lainlain, yang kesemuanya bisa dikembalikan kepada hakikat "menghimpun". ${ }^{124}$ Oleh karenannya, fokus tentang alam sekitar dan fenomenanya ini, Alqurān memerintahkan kepada manusia untuk memperhatikan dan mempelajari alam raya dalam rangka memeperoleh kemudahan-kemudahan bagi kehidupannnya, untuk

\footnotetext{
${ }^{120}$ Shihab, Membumikan..., h. 131

${ }^{121}$ Abdullah, Falsafah...., h. 180

${ }^{122}$ Q.S. al-Ahzāb (33): 72

${ }^{123}$ Shihab, Membumikan..., h. 167.

${ }^{124}$ Ibid.
} 
Aep Wahyudin, Dakwatologi Komunikasi dan Titik Bias Komunikasi

menyadarkan kesadaran akan ke-Esaan dan kekuasaan Allah SWT. ${ }^{125}$ Oleh karenya, perintah baca dikaitkan dengan "bismi rabbika"126(dengan nama Tuhanmu), perintah ini merupakan tuntutan untuk melakukan proses baca dengan keikhlasan, juga dengan memilih bahan-bahan yang dibaca yang bersesuaian dengan aturan Allah swt. ${ }^{127}$ Manifestasi ini merupakan kecintaan terhadap alam, rasa kecintaan ini digambarkan oleh seorang penya'ir Persia, yang melukiskan :

"Aku gembira dengan kosmos,

karena kosmos menerima kegembiraan dari-Nya'

Aku mencintai seluruh dunia,

Karena dunia milik-Nya". ${ }^{128}$

\section{Isti'mār: Komunikasi Pembangunan}

Islam memandang manusia sebagai wakil Tuhan di muka bumi (khalifah fil ard), ${ }^{129}$ kwalitas keterwakilan sebagi khalifah di bumi ini mengharuskan dan menugaskan untuk memakmurka alam dan bumi ini. Alqurān menegaskan: "Huwa ansha'akum min al-arḍi wa asta'marakum fihä (Dialah yang menciptakan kamu dan menugaskan untuk memakmurkannya). ${ }^{130}$ Ista'marakum berarti menjadikan dan menugaskan manusia mengolah bumi guna memperoleh manfaatnya. ${ }^{131}$ Istilah Nurchalis Madjid, menyebutnya

125 Ibid., h. 132

${ }^{126}$ Q.S. al-'Alaq (96): 1-2

${ }^{127}$ Shihab, Membumikan..., h. 168

${ }^{128}$ Seyyed Hossein Nasr, Islam and Environmental Crisis, terj. "Islam dan Krisi Lingkungan” Dalam “Islamika”, (Bandung: Mizan, 1994), h. 7, Sya'ir gubahan Sa'idi ${ }^{129}$ Q.S. al-Baqarah (2): 31

${ }^{130}$ Q.S. Hūd (11): 61

${ }^{131}$ M. Quraisy Shihab, Wawasan Alqurān, (Bandung: Mizan, 1996), h. 424 
dengan "reformasi bumi" (ị̦lah al-arộ), maka manusia dilarang berbuat kerasakan alam (bumi), tapi usaha aktif manusia untuk menciptakan sesuatu yang baru, baik dan bermaslahat. ${ }^{132}$ Komunikasi pembangunan dalam Islam bersifat menyeluruh dan seutuhnya, material dan spiritual. ${ }^{133}$

Berdasarkan pola pemahaman tersebut, tentang posisi dan tugas manusia dalam konteks komunikasi dengan alam sekitar menurut pandangan Islam, yang pada intinya berorientasi pada perubahan dari adanya pemberdayaan alam yang bermashlahat. Dapat di polarisasikan dengan gambaran sebagai berikut:

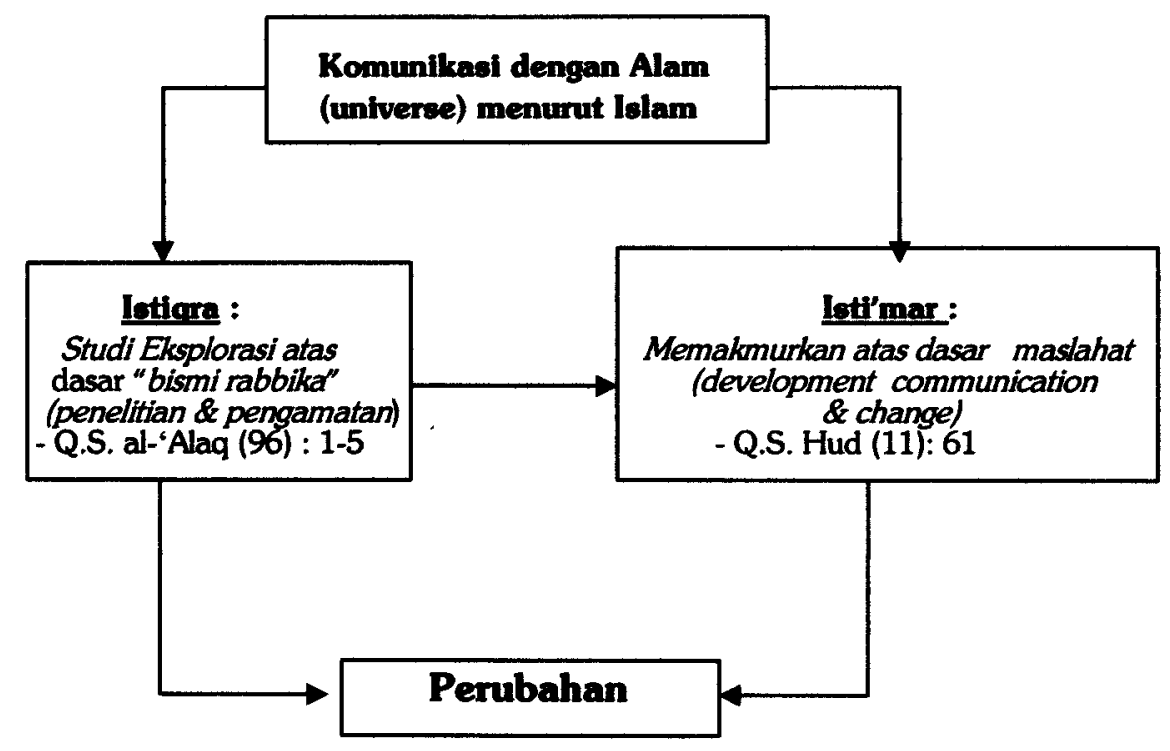

132 Nurchalis Madjid, Cendekiawan dan Religiusitas Masyarakat, (Jakarta: Paramadina, 1999), h. 31-32

${ }^{133}$ Shihab, Membumikan..., h. 301 


\section{Penutup}

Komunikasi adalah suatu disiplin ilmu yang telah memiliki "body of knowledge" tersendiri secara akademis. Dan Islam, dalam "frame of Thinking" secara studi ilmu-ilmu ke-Islaman (study of islamic science), memiliki identifikasi sinkronik dengan konsepsi teori-teori dakwah Islamiyah, yang telah berusaha menjelma dan memiliki bangunan ilmu (body of knowledge) tersendiri, sebagai sebuah disiplin ilmu dakwah. Dengan tetap mendeduktifikasi dari "grand reference", Alqurān dan Alhadith.

Oleh karena itu, untuk menjawab absurditas masalah-masalah komunikasi tersebut, adalah dengan menggunakan pendekatan antar disipliner komunikasi dan dakwah, dan pendekatan ayat-ayat Alqurān yang secara eksplisit maupun implisit berhubungan dengan komunikasi. Dan pola jawaban yang digunakan, adalah dengan uraian sistematis, mengingat perlunya penjelasan jawaban uraian yang analitik dari kedalaman masalah permasalahan tersebut.

Membangun paradigma komunikasi Islam, sesungguhnya tidak harus dimulai dari nol. Dasaran sintesisnya dapat menggunakan teori-teori komunikasi konvensional (Barat), namun yang menjadi Homework bagi para intelektual Muslim adalah membuat sintesis baru melalui aspek methatheory yang meliputi epistemologi, ontologi dan perspektif. Pembenahan pada aspek dimensi nilai dan etika harus dapat berkolaborasi dengan ketauhidan dan tanggungjawab ukhrawi. Fungsi komunikasi Islam adalah untuk mewujudkan persamaan makna, dengan demikian akan terjadi perubahan sikap atau tingkah laku pada masyarakat Muslim

Komunikasi Islam merupakan bentuk frasa dan pemikiran yang baru muncul dalam penelitian akademik sekitar tiga dekade belakangan ini. Munculnya pemikiran dan aktivisme komunikasi Islam didasarkan pada 
kegagalan falsafah, paradigma dan pelaksanaan komunikasi Barat yang lebih mengoptimalkan nilai-nilai pragmatis, materialistis serta penggunaan media secara kapitalis. Kegagalan tersebut menimbulkan implikasi negatif terutama terhadap komunitas Muslim di seluruh penjuru dunia akibat perbedaan agama, budaya dan gaya hidup dari negara-negara (Barat) yang menjadi produsen ilmu tersebut.

Dalam aspek holitis, universe, spiritualitas, subtansi nilai perubahan individual-sosial-kultual dan pemberayaan masyarakat, komunikasi Barat cenderung bersifat positivistik dan fungsional-pragmatis yang berorientasi kepada individu (parochial) dan 'temporal time oriented', bukan kepada keselurusan sistem sosial dan fungsi sosiobudaya yang sangat penting untuk merangsang terjadinya perubahan sosial. Kualitas komunikasi menyangkut nilai-nilai kebenaran, kesederhanaan, kebaikan, kejujuran, integritas, keadilan, kesahihan pesan dan sumber, menjadi aspek penting dalam komunikasi Islam. Oleh karenanya dalam perspektif ini, komunikasi Islam ditegakkan atas sendi hubungan segitiga (islamic triangular relationship), antara "Allah, manusia dan' manusia (masyarakat)"

Dalam Islam prinsip informasi bukan merupakan hak eksklusif dan bahan komoditi yang bersifat value-free, tetapi ia memiliki norma-norma, etika dan moral imperatif yang bertujuan sebagai service membangun kualitas manusia secara paripurna. Jadi Islam meletakkan inspirasi tauhid sebagai parameter pengembangan teori komunikasi dan informasi. Alquran menyediakan seperangkat aturan dalam prinsip dan tata berkomunikasi.

\section{Daftar Pustaka}

Abdullah, M. Amin. Falsafah Kalam di Era Post Modemisme, Yogyakarta: Pustaka Pelajar, 1995 
Aep Wahyudin, Dakwatologi Komunikasi dan Titik Bias Komunikasi

Ahmad, Amrullah, Kurikulum Nasional Fakultas Dakwah IAIN. Tim Penyusun, 1994

Dakwah Islam dan Perubahan Sosial, Yogyakarta: PL2M, 1985

An Nawawy, Riyadu al-Sälihîn, terjemah oleh Salim Bahreisy, Bandung: PT. Al-Ma'arif, 1987.

An Nawawy, Syarifuddin, Matan al-'Arba'in, Jakarta: At-Ṭahiriyah, 1985

Aubrey, A., Teori-teori Komunikasi, Bandung: Rosda Karya, 1986

Al-Abady, Mujiduddin Muhammad Bin Ya'kub Al-Fairuz, Basa'ir Zawit Tamyiz fi Lathā'if al-Kitäbil Aziz, Bairut: Al-Maktabah Al-'Ilmiyah, th.

Anshari, M. Hafi, Pemahaman dan Pengamalan Dakwah, Surabaya: AlIkhlas, 1993

Azzaid, Zaid Abdul Karim, Al-Hikmah Fi al-Da'wah ilā Allāh, terj. "Dakwah bi al-Hikmah", Jakarta: Pustaka al-Kauthar, 1993

Barker, Lary, Communication", New Jersey: Prantic Hall, 1984

Bachtiar, Wardi, Metodologi Penelitian Ilmu Dakwah, Bandung; Logos, 1997.

Cowan, J. Milton, A Dictionary of Written Arabic, London: Goerge Allah and Uniwin, 1971

Dahlan, H.M.D., Asbabun Nuzul, Bandung: Cv. Diponegoro, 1995

Depag RI., Alqurān dan Terjemahnya, Bandung: Gema Risalah Press, 1992.

Devito, A., Recognizing and Assesing Creativity, in Jweigand "Development Teacher Competenties", New Jersey: Prentic Hall inc., 1978.

Effendi, Onong Uchyana, Ilmu Komunikasi Teori dan Praktek, Bandung: Rosda Karya, 1994

------, Kamus Komunikasi, Bandung: Mandar Maju, 1989

------, Dinamika Komunikasi, Bandung: Rosda Kary, 1993

Hadad, Abdullah Habib, al-Nashā'ih al-Diniyāh wa al-Washaya alImãmah", terj. "Nasihat Agama dan Wasiat Iman". Bandung: Gema Risalah Press, 1993

Hasan, Ibrahim Hasan, Tarikh al-Islām, Kairo al-Nāḍrah al-Miṣriyyāh, 1965 
Hasanudin, A. H., Retorika Dakwah dan Publisistik, Surabaya: Usaha Nasional, 1982

Hasymy, A., Dustur Dakwah Menurut Alqurān, Jakarta: Bulan Bintang, 1994

Kafie, Jamaluddin, Psikologi Dakwah, Surabaya: Ofsett Indah, 1993

Kustawa, R. Agus Toha, Komunikasi Islam, Jakarta: Arikha Media Cipta, 1986

Khaliq, Abdurrahman Abdul, Fusūlun Min al-Shiasāti Shar'yati fi al-Da'wah ilā Allāh, terj. "Metode dan Strategi Dakwah Islam", Jakarta: Pustaka Al-Kautsar, 1996

Mahfuzh, Syekh Ali, Hidāyatu al Murshidīn, Bairut: Där al-Ma'arif, th.

Makluf, Louis, Al-Munì̃ fi al-Lughāh wa al-'Adab, Bairut: Matbā'ah Kastulkiyah, tth.

Masyhur, Al Ustadz Mushțafa, Qudwāh Alā al-Ṭariq al-Da'wah, terj. "Qudwah Di Jalan Dakwah", Solo: Citra Islami Press, 1996

Muhammad, Ahmad Kamil, Communication As An Academic Discipline, terj. "Komunikasi Sebagai suatu Disiplin Akademis". Disarikan dari Litlejohn SW, "Theories of Human Communication". Dalam Jurnal komunikasi Audienta, Bandung: Rosda Karya, 1993

Muhtaron, Zaini, Dasar-dasar Manajemen Dakwah, Yogyakarta: al-Amin, 1996.

Mulkhan, Abdul Munir, Paradigma Intelektual Muslim, Yogyakarta: Sipres, 1994.

Nasution, Harun, Islam Ditinjau dari Berbagi Aspeknya, Jakarta: UI Press, 1985

Nasr, Seyyed Hossein, Islam Tradisi Di Kancah Dunia Modem, Bandung: Pustaka, 1994

Sains dan Peradaban Islam, Bandung: Pustaka, 1985.

---------, Islam and Environmental Crissis, terj. "Islam dan Krisis Lingkungan" Dalam Islamika, Bandung: Mizan, 1994

Nuh, Sayyid Muhammad, Affătun Alā al-Tariq al-Harakah, terj. "Terapi Mental Aktivis Harakah", Solo: CV. Pustaka Mantiq, 1995

Nurchalis, Madjid, Cendekiawan dan Religiusitas Masyarakat, Jakarta: Paramadina, 1999 
Aep Wahyudin, Dakwatologi Komunikasi dan Titik Bias Komunikasi

Quțub, Sayyid. Tafsir Fi dillali Alqurān. Bairut : Ihyāut Turāsi al-'Araby, th.

------, Fiqhu Da'wah Maudu'at fil al-Da'wah al-Harakah, Bairut: Muassasah al-Risalah, 1970.

Rakhmat, Jalaluddin, Retorika Modern: Pendekatan Praktis. Bandung: Rosda Karya, 1994

--..-.-.-.-, Psikologi Komunikasi, Bandung: Rosda karya, 1996

Rousydi, Lathief TA., Dasar-dasar Retorika Komunikasi dan Informasi, Jakarta: Rimbaw Medan, 1985

Sambas, Syukriadi, Ușul al-Ithna' al-Asha'riyāh, Terj. "Pedoman Matan Wilayah Dakwah Islam", Bandung: Fakultas Dakwah IAIN SGD, 1998.

, Transendetalisme. Suatu Bagian Dari Metode Ilmiah, Dalam Mimbar Studi, Bandung: IAIN SGD, 1995

Shihab, M. Quraish, Membumikan Alqurān, Bandung: Mizan, 1995

---------, Wawasan Alqurān, Bandung: Mizan, 1996

Siddiq, Syamsuri, Dakwah dan Teknik Berkhutbah, Bandung: PT. AlMa'rif, 1981

Subandi, Ahmad, Ilmu Dakwah, Bandung: Yayasan Syahida, 1994

Solatun, Islam dan Etika Komunikasi: Studi Interpretatif Tentang Pendekatan Etis dalam Komunikasi antar Ummat Berbeda Agama menurut Studi Pandang Islam Tekstual, Dalam Tesis Pascasarjana UNPAD Bandung, 1994

Wijono, Harun, Sari-sari Sejarah Filsafat Barat, Jakarta: Kanisius, 1994

Ya'kub, Hamzah, Publisistik Islam Teknik Dakwah Dan Leadership, Bandung: CV. Diponegoro, 1981 